\title{
Assessing the effects of no-till on SOC dynamics throughout the soil profile after grassland renovation and conversion to silage maize
}

\author{
Josue De Los Rios ${ }^{1 *}$, Arne Poyda ${ }^{1}$, Thorsten Reinsch ${ }^{1}$, Christof Kluß ${ }^{1}$, Ralf Loges ${ }^{1}$, Friedhelm Taube ${ }^{1,2}$ \\ ${ }^{1}$ Institute of Crop Sciences and Plant Breeding, Grass and Forage Sciences/Organic Agriculture, Christian-Albrechts- \\ 5 University, Kiel, Germany \\ ${ }^{2}$ Grass-based Dairy Systems, Animal Production Systems Group, Wageningen University (WUR), Wageningen, Netherlands \\ Correspondence to: Josue De Los Rios (jriosmera@gfo.uni-kiel.de)
}

\begin{abstract}
Land-use change (LUC) and conventional tillage (CT) result in the reduction of the high soil organic carbon (SOC) stocks stored in grassland ecosystems during their conversion and renovation, contributing to global warming. While plenty studies show the use of no-tillage (NT) as a promising option to increase the topsoil SOC stocks of arable lands, its potential to conserve SOC during grassland conversion and renovation events has been poorly investigated. Further, the effects of LUC and tillage methods on the SOC dynamics have been limited to the topsoil by most studies, thus overlooking their impact on the subsoil where significant amounts of SOC are stored, and changes in vegetation and residue distribution can negatively affect these. In this study, a 10-year-old grassland was converted to continuous silage maize (CM) using NT (NT-CM) and CT
\end{abstract}

15 (CT-CM), and renovated using NT (NT-GR), while some part remained undisturbed as a control (GC). The systems were either non-fertilized (N0) or fertilized according to a demand of 180 and $380 \mathrm{~kg} \mathrm{~N} \mathrm{ha}^{-1} \mathrm{yr}^{-1}$ (N1) in the silage maize and grassland systems, respectively. SOC stocks were measured annually and annual SOC changes ( $\triangle \mathrm{SOC}$, in $\mathrm{Mg} \mathrm{Cha}^{-1} \mathrm{yr}^{-1}$ ) were calculated for different soil layers $(0-30,30-60$ and $60-90 \mathrm{~cm})$ and across the whole profile $(0-90 \mathrm{~cm})$ over a 6-year period (2014-2020). Annual soil carbon inputs $\left(\mathrm{C}_{\mathrm{i}}\right)$ via plant residues were quantified and related to $\triangle \mathrm{SOC}$. Results showed that cropping systems significantly affected SOC dynamics over time. At 0-30 cm, SOC stocks were significantly reduced after conversion using both tillage methods, however, $44 \%$ lower annual losses were obtained in NT-CM (-1.5 Mg C ha- $\left.\mathrm{yr}^{-1}\right)$ compared to CT-CM (-2.7 $\left.\mathrm{Mg} \mathrm{C}^{-1} \mathrm{yr}^{-1}\right)$. Conversely, SOC stocks remained unchanged after NT-GR same as the GC. In the subsoil, SOC stocks increased under GC (1.1 $\left.\mathrm{MgC} \mathrm{ha}^{-1} \mathrm{yr}^{-1}\right)$ and remained unchanged in the other systems. Across the whole profile, SOC stocks increased in GC, remained stable in NT-GR, and decreased in NT-CM and CT-CM with mean annual change rates of $1.3,-0.1,-1.9$ and $-3.4 \mathrm{Mg} \mathrm{Cha}^{-1} \mathrm{yr}^{-1}$, respectively. The differences in $\triangle \mathrm{SOC}$ between the unploughed systems (NT-GR, NT-CM and GC) were strongly related to the annual soil $\mathrm{C}_{\mathrm{i}}$ from plant residues in the topsoil. Our findings highlight the great potential of NT to slow down the annual SOC losses after grassland conversion or renovation, and that C sequestration can occur in the subsoil of permanent grasslands when the topsoil $\mathrm{C}$ is already saturated. This strengthens the need to consider the SOC changes occurring in the whole profile after a LUC event. 
https://doi.org/10.5194/bg-2022-6

Preprint. Discussion started: 7 February 2022

(c) Author(s) 2022. CC BY 4.0 License.

(c) (i)

\section{Introduction}

Land-use change (LUC) and conventional tillage (CT) by ploughing often result in the reduction of the high soil organic carbon (SOC) stocks stored in grassland ecosystems. This reduction of SOC stocks can be up to two thirds within a few decades after conversion to arable land use, and up to a quarter within the first years after a single renovation event (Guo and Gifford, 2002; Necpálová et al., 2014; Reinsch et al., 2018a; Kayser et al., 2018). With these losses, soil fertility is reduced and great amounts

35 of carbon dioxide $\left(\mathrm{CO}_{2}\right)$ and other greenhouse gases of greater warming potential (e.g., nitrous oxide) are released, contributing to the anthropogenic-related global warming (Velthof et al., 2010; Reinsch et al., 2018b). Reducing or even ceasing the use of $\mathrm{CT}$ and replacing it with less intensive soil management, like reduced (RT) and no-tillage (NT) during conversion and renovation are proposed as avenues not only to reduce SOC losses but also to conserve them (Diabate et al., 2018; Kern and Johnson, 1993; Thorn et al., 2011).

40 Some studies suggest that replacing CT with NT can increase SOC stocks by at least $0.3 \mathrm{Mg} \mathrm{ha}^{-1} \mathrm{yr}^{-1}$ in the top $30 \mathrm{~cm}$ soil layer of arable land (West and Marland, 2002; West and Post, 2002). According to IPCC (2019), this replacement can increase SOC stocks by $10 \%$ annually across temperate and tropical wet climates (Ogle et al., 2019b). While some evidence of its benefits is available for changing tillage methods in established arable lands, little research has been done in observing the use of NT for SOC conservation during grassland conversion and renovation, thus, potentially limiting its application when the

45 destruction of grasslands seems unavoidable (Guo and Gifford, 2002). Few findings from limited locations suggest that SOC can be conserved after conversion and renovation, at the same level as an unploughed adjacent grassland site (Franzluebbers and Stuedemann, 2008; Follett et al., 2009). However, more studies are yet required for site conditions like the ones in temperate wet climates, where both high organic carbon inputs and SOC decomposition are combined, and a reduction in crop residue inputs might follow after conversion or renovation.

50 No less important is to consider the effects of LUC and tillage methods on deeper soil layers. LUC can affect SOC in the subsoil indirectly through the change in vegetation when for example perennial forages are displaced by annual crops (VandenBygaart et al., 2011; Ellert et al., 2008; Jobbagy and Jackson, 2000). Both vertical root growth from taproots and high rhizodeposition production in perennial forages can mobilize $\mathrm{C}$ below the tillage layer and throughout the soil profile, in the form of dissolved organic carbon (DOC) (Johnson et al., 2006; Lal and Follett, 2009; Nüsse et al., 2018). Increasing SOC

55 stocks in the subsoil have been observed in the arable to grassland conversion (Gentile et al., 2005; Guo and Gifford, 2002), while the opposite was reported for grassland conversion or cessation (Don and Schulze, 2008; MacDonald et al., 2011). Furthermore, tillage methods can affect the vertical distribution of crop residues, thereby affecting SOC in the subsoil. While CT incorporates crop residues into the soil directly, thereby increasing their contact to microorganisms and to the soil matrix, NT accumulates these on the soil surface, limiting its decomposition and movement to the subsoil (Paul et al., 1996; Reinsch

60 et al., 2021; Luo et al., 2010; Angers and Eriksen-Hamel, 2008). A major criticism of many studies is that they have been restricted to measure SOC changes in the topsoil where ploughing takes place, neglecting potential changes occurring in the subsoil during conversion and renovation (Gál et al., 2007; Ogle et al., 2019a). Therefore, the effects of LUC- and tillage- 
https://doi.org/10.5194/bg-2022-6

Preprint. Discussion started: 7 February 2022

(c) Author(s) 2022. CC BY 4.0 License.

(c) (i)

induced effects on SOC stocks over the whole soil profile need to be studied more intensively (VandenBygaart et al., 2011; Luo et al., 2010; Lal and Follett, 2009).

65 In this study, the effects of LUC and tillage methods on SOC stocks after the conversion to silage maize cropping or renovation of a 10-year-old permanent grassland are assessed for the 0-90 $\mathrm{cm}$ soil layer over 6 years. We hypothesize that 1) no-till can reduce SOC losses after LUC from grassland to arable land and maintain SOC stocks when used for grassland renovation, 2) the conversion or renovation of a permanent grassland negatively affects subsoil SOC, and 3) soil C inputs from plant residues are the main controlling factor for SOC change rates in no-till systems.

\section{Material and Methods}

\subsection{Study site}

The long-term experiment was located at the research farm "Hohenschulen" of the Christian-Albrechts-University of Kiel in northwest Germany $\left(54^{\circ} 31^{\prime} \mathrm{N}\right.$; $9^{\circ} 19^{\prime} \mathrm{E}$; $30 \mathrm{~m}$ a.s.l.). The climate is maritime with a mean annual temperature of $8.9^{\circ} \mathrm{C}$ and a mean annual precipitation of $847 \mathrm{~mm}$ (1978-2010). The dominant soil type is stagnic Luvisols (FAO classification) with a sandy loam texture (Table 1), and organic C contents between 1 and $1.5 \%$. The site has a slope of 9-11 ${ }^{\circ}$. Due to this, very high variability in subsoil SOC stocks between the upper and lower half of the site was observed, most likely as a result of historical erosion and sedimentation processes. To exclude these site-specific effects, this study only reports results from the upper half of the experimental site.

Before 2015, a 10-year-old seeded grassland experiment ( established in 2004) organized in a split-plot design was located on

80 the field, comparing different cutting frequencies ( $3 \mathrm{vs} 5$ cuts $\mathrm{yr}^{-1}$ ) as main factor and $\mathrm{N}$ fertilization levels ( $0 \mathrm{vs} 360 \mathrm{~kg} \mathrm{~N}$ ha $\left.{ }^{1} \mathrm{yr}^{-1}\right)$ as subplot factors in $6 \times 6 \mathrm{~m}$ plots. The established grassland consisted of a mixture of different grass and legume species, including Lolium perenne, Festuca pratensis, Poa pratensis, Phleum pratense, Dactylis glomerata, Trifolium repens, and Medicago sativa. Between 2005 and 2014, the botanical composition of the swards differed between the treatments, dominated by Medicago sativa and Trifolium repens from the legume species, and by Dactilys glomerata and Lolium perenne from the

85 grass species in the 3- and 5-cut treatments, respectively (Nüsse et al., 2018; Schmeer et al., 2014). Despite these differences, by the end of 2014 the SOC stocks barely differed between the pre-management levels in the different soil layers (provided in Supplementary: Table S1, S2 and S3).

In spring 2015, three new cropping systems were introduced randomly into the previous grassland sward. Part of the grassland was converted to a continuous silage maize system (CM) using CT and NT, part of the grassland was renovated (GR) using

90 NT, and part remained unchanged as a control (GC). In addition to the new cropping systems, two $\mathrm{N}$ application levels were introduced using calcium ammonium nitrate (CAN). The N levels were non-fertilized (N0) and fertilized with CAN (N1), according to a demand of $180 \mathrm{~kg} \mathrm{~N} \mathrm{ha}^{-1} \mathrm{yr}^{-1}$ for the silage maize systems and $380 \mathrm{~kg} \mathrm{~N} \mathrm{ha}^{-1} \mathrm{yr}^{-1}$ for the cut-used grassland systems. The number of replicates used in each treatment in this study is provided in Appendix A: Table A1. A diagram of the 
https://doi.org/10.5194/bg-2022-6

Preprint. Discussion started: 7 February 2022

(c) Author(s) 2022. CC BY 4.0 License.

(c) (i)

pre-management factors existing between 2004 and 2014, and the treatments introduced in the current study from 2015 is provided in Supplementary: Figure S1.

At the experimental setup, all plots except for the GC plots were sprayed with glyphosate-containing herbicides (Round-Up Ultra and Round-Up Powerflex). Plots with the CT treatment were subsequently rotovated $(10 \mathrm{~cm} \mathrm{depth})$, mouldboard ploughed ( $25-30 \mathrm{~cm}$ depth), and treated with rotary harrow for seedbed preparation. The plots with the NT treatment received no soil cultivation. The seeding was performed with direct drilling seeders in both CM systems (Horsch, Germany) and the GR treatment (Vredo, Netherlands). The maize (Zea Mays) variety Ronaldinio (KWS) was sown each year in May at a rate of 10.5 seeds $\mathrm{m}^{-2}$, with a row distance of $0.75 \mathrm{~m}$ and at a sowing depth of $5 \mathrm{~cm}$. In the GR treatment, a 5:1 seed mixture of Lolium perenne to Trifolium repens was sown at a rate of $40 \mathrm{~kg} \mathrm{ha}^{-1}$ once in spring 2015. Nutrients besides $\mathrm{N}(\mathrm{P}, \mathrm{K}, \mathrm{Mg}$, and $\mathrm{S}$ ) were supplied in sufficient amounts at the beginning of the growing season to avoid nutrient deficiencies. Further details about the management can be found in Struck et al. (2019).

\subsection{Measurements}

\subsubsection{Soil sampling and carbon analysis}

SOC concentration was measured annually from 2014 (the year prior conversion) to 2020 at three different soil layers, namely 0-30, 30-60, and 60-90 cm, at the end of each growing season. To do so, a sample from each plot was collected using a hydraulic-driven soil auger (inner $\varnothing 2 \mathrm{~cm}$ ), oven-dried at $30^{\circ} \mathrm{C}$, and sieved to pass a $2 \mathrm{~mm}$ mesh size for further analyses. The

$110 \mathrm{C}$ and $\mathrm{N}$ contents were determined using a CN elemental analyzer (Vario Max CN, Elementar) (ISO).

To calculate SOC stocks, soil bulk density measurements were conducted in 2020 in all the treatments at $15 \mathrm{~cm}$ soil depth just before tillage in CT-CM. No significant differences between soil bulk densities were detected between the treatments. Therefore, the mean soil bulk density of $1.61 \mathrm{~g} \mathrm{~cm}^{-3}$ was adopted in all treatments for the 0-30 $\mathrm{cm}$ soil layer, regardless of the tillage treatment. To calculate SOC stocks for the 30-60 and 60-90 cm soil layers, a soil bulk density of 1.65 and $1.70 \mathrm{~g} \mathrm{~cm}^{-3}$

115 was assumed, respectively, based on the boulder clay features of the subsoil layers (Struck et al., 2019).

\subsubsection{Plant biomass sampling and soil C input calculations}

The annual crop yields $\left(\mathrm{Y}_{\mathrm{P}}\right)$ in the CM systems were obtained using a two-row plot harvester (Kemper 1200, Haldrup, Logstor, Denmark) at the silage maturity stage, at a stubble height of $25 \mathrm{~cm}$. After harvesting, the stubbles were left on the soil surface in the NT system, whereas in the CT system these remained on the field until their incorporation via tillage, before sowing.

120 The grassland systems were harvested with a cutting frequency of 4 cuts $\mathrm{yr}^{-1}$ (May, Jul, Aug, and Oct), using a forage plot harvester (Haldrup, Logstor, Denmark) at a cutting height of $5 \mathrm{~cm}$. Dry matter yields were determined from fresh matter subsamples that were oven-dried at $58{ }^{\circ} \mathrm{C}$ to estimate their humidity content. The mean annual yields $\left(\mathrm{Y}_{\mathrm{P}}\right)$ measured for the period 2015 - 2020 are provided in Supplementary: Table S4. 
https://doi.org/10.5194/bg-2022-6

Preprint. Discussion started: 7 February 2022

(c) Author(s) 2022. CC BY 4.0 License.

\section{(c) (i)}

To obtain yield-based allocation coefficients, total above- (AGB) and belowground biomass (BGB) measurements conducted during and after the growing seasons (March - October and November - March , respectively) by Struck (2018) in the years 2015 and 2016 were used. During the growing season, AGB samples were taken at each grassland cutting and maize harvest on an area of 0.25 and $1 \mathrm{~m}^{2}$ in 4 plots, at a cutting height of 5 and $25 \mathrm{~cm}$, respectively, and separated into harvestable biomass and stubbles. In the same plots, BGB was measured using the ingrowth core method (Steingrobe et al., 2001), starting from mid-March and following the grassland cutting intervals (every 6 weeks). Roots were washed from soil using a hydropneumatic elutriation system (Smucker et al., 1982) and collected using a screen with a mesh size of $0.63 \mathrm{~mm}$. After drying the samples, the ash-corrected dry matter (ACDM) and carbon contents were determined for both AGB and BGB samples. Harvest (HI) and stubble indices (SI) were calculated by the ratio of $Y_{P}$ and stubbles to total AGB, respectively. The R:S was determined by the ratio between the annual sums of the ash-corrected BGB and AGB. To determine the BGB produced after the growing season, the same method was applied as explained above, using the cumulative biomass of three sampling dates (Nov, Feb, and Mar). A detailed description of the measurements is available in Struck (2018).

The annual soil $C$ inputs $\left(C_{i}\right)$ were estimated system wise, using the measured $Y_{P}$ and yield-based allocation coefficients to calculate the above $(\mathrm{AG})$ and belowground $(\mathrm{BG}) \mathrm{C}_{\mathrm{i}}$ produced during the growing season, and adding fixed inputs to account for the residues produced $\mathrm{AG}$ and $\mathrm{BG}\left(\mathrm{AW}-\mathrm{AG}_{\mathrm{i}}\right.$ and $\mathrm{AW}-\mathrm{BG}_{\mathrm{i}}$, respectively) in the grassland systems after the growing season. For the AG residues produced during the growing season, stubbles were calculated using the estimated SI in the CM systems, whereas in the grassland systems harvest residues and litter deposition were calculated using a SI equal to $15 \%$ on a DM basis, as proposed by Bolinder et al. (2007). The BG residues produced in the same season were calculated using the mean ashcorrected R:S ratios measured in the first two years. For the fixed inputs produced after the growing season in the grassland systems, measured BGB of the first two experimental years was used. Since AGB was not measured in this period, we assumed these inputs using measured AGB in winter from a similar grassland experiment located at a nearby experimental farm (Loges et al., 2018). To account for extra inputs derived from rhizodeposition, an additional $50 \%$ of the total BGB produced during and after the growing season was added to the $\mathrm{BG} \mathrm{C}_{\mathrm{i}}$ calculations, as suggested by Pausch and Kuzyakov (2018). Ash-corrected dry matter (ACDM) values were used for the $\mathrm{C}_{\mathrm{i}}$ calculations, as these are preferred to total dry matter (Bolinder et al., 2007). Carbon content of $48 \%$ was calculated on the ash-corrected AG and BG plant material. The steps and equations used to calculate annual soil $\mathrm{C}$ inputs in each cropping system, using the annual yields $\left(\mathrm{Y}_{\mathrm{P}}\right)$ and using the yield-based allocation coefficients and fixed inputs are provided in Supplementary: Tables S5 and S6.

\subsection{Statistical analysis}

The interaction of the factors cropping system, $\mathrm{N}$ rate and soil layer with time (year) were tested for their effects on SOC stocks, using analysis of covariance (ANCOVA) within a linear mixed-effects model. To do so, the lme package (Bates et al. 2015) was used in R statistical software (R Core Team, 2020). Three separate ANCOVAs were performed: one using all the

155 treatments to assess the influence of the cropping systems and $\mathrm{N}$ rates on $\triangle \mathrm{SOC}\left(\mathrm{Mg} \mathrm{C} \mathrm{ha}^{-1} \mathrm{yr}^{-1}\right)$ in the different soil layers after grassland conversion (i.e., the LUC), another using only the CM systems to assess the influence of tillage method and $\mathrm{N}$ 
https://doi.org/10.5194/bg-2022-6

Preprint. Discussion started: 7 February 2022

(c) Author(s) 2022. CC BY 4.0 License.

(c) (i)

rates on $\triangle \mathrm{SOC}$ after conversion, and a third one using all the treatments to assess the influence of $\mathrm{CS}$ and $\mathrm{N}$ rates on $\triangle \mathrm{SOC}$ across the soil profile $(0-90 \mathrm{~cm})$. When the study factors significantly interacted with time, separate regressions were estimated and tested whether the mean $\triangle \mathrm{SOC}$ statistically differed from zero. All the tested effects were considered significant with a pvalue $<0.05$.

In addition, the changes in $\triangle \mathrm{SOC}$ by a unit change in annual soil $\mathrm{C}_{\mathrm{i}}$ were calculated by linear regression in the $0-30 \mathrm{~cm}$ soil layer, using the observations of the unploughed systems (GC, NT-GR, and NT-CM) (Ferreira et al., 2012; Johnson et al., 2006). The minimum amount of annual $\mathrm{C}_{\mathrm{i}}$ required to maintain the SOC stocks at its initial levels $(\Delta \mathrm{SOC}=0)$ was calculated using the regression estimates, by solving for $\mathrm{x}$ when $\mathrm{y}=0$.

\section{Results}

\subsection{Soil layer-specific effects of grassland conversion and renovation on soil organic carbon stocks}

After grassland conversion and renovation, the SOC stocks were significantly affected by the interaction between soil layer, cropping system and year $(\mathrm{p}<0.001$, Table 2$)$, thus the development of SOC over the years differed between the cropping systems and soil layers. However, there was no significant effect or interaction induced by the different $\mathrm{N}$ rates. This was the same for the analysis with the CM systems only, where the ANCOVA revealed significant effects over time induced by the tillage method $(\mathrm{p}<0.01)$ and the soil layer $(\mathrm{p}<0.001)$, but not by the $\mathrm{N}$ rates (Table 3). Since the $\mathrm{N}$ rates showed no significant influence nor any interaction over the years, cropping systems were pooled over the $\mathrm{N}$ rates and separated by soil depth.

Table 2

Table 3

175 At the 0-30 cm layer, significant SOC losses over time were observed in CM for both tillage methods ( $\mathrm{p}<0.0001$, Figs 1 and 2). By using NT during conversion, SOC losses were reduced from -2.7 to $-1.5 \mathrm{Mg} \mathrm{C} \mathrm{ha}^{-1} \mathrm{yr}^{-1}$, equal to $44 \%$ lower annual SOC losses. By the end of the study period, SOC stocks in CT-CM and NT-CM had decreased by 23 and $12 \%$ (-3.8 and -2.0 $\left.\% \mathrm{yr}^{-1}\right)$, respectively, in relation to the initial SOC levels before conversion. In contrast, SOC stocks remained unchanged in the topsoil of NT-GR and GC.

180 In the subsoil, significant increases in SOC was observed only in GC at the 30-60 $\mathrm{cm}$ layer $\left(1.1 \mathrm{Mg} \mathrm{C}^{-1} \mathrm{yr}^{-1}, \mathrm{p}<0.01\right.$, Figs 1 and 2). In the other systems, no significant changes in SOC stocks were observed after conversion or renovation by using any of the tillage methods. At the $60-90 \mathrm{~cm}$ soil layer, $\triangle \mathrm{SOC}$ was not significant in all four cropping systems.

Figure 1

Figure 2

\section{3.2 Effects of grassland conversion and renovation on soil organic carbon stocks in the whole profile}

When SOC stocks were summed up across the whole soil profile $(0-90 \mathrm{~cm})$, they were significantly affected by the cropping systems over time ( $\mathrm{p}<0.001$, Table 4). The $\Delta$ SOC was significantly negative in both CT-CM (p < 0.0001) and NT-CM (p < 
https://doi.org/10.5194/bg-2022-6

Preprint. Discussion started: 7 February 2022

(c) Author(s) 2022. CC BY 4.0 License.

(c) (i)

0.01) with losses of -3.4 and $-1.9 \mathrm{Mg} \mathrm{C} \mathrm{ha}^{-1} \mathrm{yr}^{-1}$, respectively. In the grassland systems, highly positive but non-significant $\triangle \mathrm{SOC}$ was observed for GC (1.3 Mg C ha $\left.{ }^{-1} \mathrm{yr}^{-1}\right)$, whereas SOC remained unchanged in NT-GR (-0.1 Mg Cha-1 $\left.\mathrm{yr}^{-1}\right)$ (Figs 3 and 4).

Table 4

Figure 3

Figure 4

\subsection{Effects of soil C inputs on topsoil SOC stocks}

195 The mean annual soil $C_{i}$ for the period 2015-2020 are shown in Table 5. After grassland conversion to CM, the total $C_{i}$ decreased by $72 \%$ (from 6.4 to $1.8 \mathrm{Mg} \mathrm{C} \mathrm{ha}^{-1} \mathrm{yr}^{-1}$ ) when averaged over $\mathrm{CM}$ systems and $\mathrm{N}$ rates, whereas after grassland renovation, total $\mathrm{C}_{\mathrm{i}}$ decreased by $13 \%$ (from 6.8 to $6.0 \mathrm{Mg} \mathrm{C} \mathrm{ha}^{-1} \mathrm{yr}^{-1}$ ) compared to the $\mathrm{GC}$. The reduced $\mathrm{C}_{\mathrm{i}}$ after conversion was mainly due to lower $\mathrm{BG} \mathrm{C}_{\mathrm{i}}$ with an $82 \%$ reduction (from 5.6 to $1 \mathrm{Mg} \mathrm{C} \mathrm{ha}^{-1} \mathrm{yr}^{-1}$ ) compared to $33 \%$ lower $\mathrm{C}_{\mathrm{i}}$ from AGB (from 1.2 to $0.8 \mathrm{Mg} \mathrm{Cha}^{-1} \mathrm{yr}^{-1}$ ). After grassland renovation, $\mathrm{BG} \mathrm{C}_{\mathrm{i}}$ decreased by $13 \%$ (from 5.6 to $4.9 \mathrm{Mg} \mathrm{C} \mathrm{ha}^{-1} \mathrm{yr}^{-1}$ ), whereas AG $\mathrm{C}_{\mathrm{i}}$ decreased by $8 \%$ (from 1.2 to $1.1 \mathrm{Mg} \mathrm{Cha}^{-1} \mathrm{yr}^{-1}$ ). Only marginal differences between the $\mathrm{C}_{\mathrm{i}}$ of the two tillage methods in the CM systems were observed. In all four systems, $\mathrm{N}$ fertilization increased $\mathrm{AG}_{\mathrm{i}}$, while it reduced $\mathrm{BG} \mathrm{C}_{\mathrm{i}}$ except for CT$\mathrm{CM}$ where it remained unchanged.

Table 5

The linear regression of $\triangle \mathrm{SOC}$ against total annual soil $\mathrm{C}_{\mathrm{i}}$ (Fig. 5) for the no-till systems (GC, NT-GR, and NT-CM) indicated

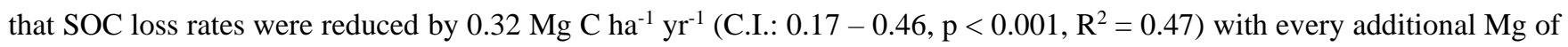
$\mathrm{C}_{\mathrm{i}}$ from plant residues. Approximately $6.5 \mathrm{Mg} \mathrm{C}_{\mathrm{i}} \mathrm{ha}^{-1} \mathrm{yr}^{-1}$ from plant residues were required across $\mathrm{N}$ rates to maintain the SOC stocks at the initial level ( 75 $\left.\mathrm{Mg} \mathrm{SOC} \mathrm{ha}^{-1}\right)$.

Figure 5

\section{Discussion}

\subsection{No-till (NT) effects on topsoil SOC stocks after grassland conversion and renovation}

The use of NT has frequently been designated as a promising measure to maintain or increase SOC stocks in arable lands (West and Post, 2002; West and Marland, 2002). However, its suitability to conserve SOC after grassland renovation and conversion to arable land, particularly over several years, has barely been studied. In this study, it was hypothesized that NT can reduce SOC losses after LUC from grassland to arable land and maintain SOC stocks when used for grassland renovation.

215 In agreement with the initial hypothesis, annual SOC losses were reduced by almost half when NT was used instead of CT, despite the observed substantial losses (Figs 1 and 2).

These results both agree and disagree with those of previous research with a similar experimental setup, but with different site conditions. Our study showed a similar reduction in annual SOC losses $\left(\sim 1.2 \mathrm{Mg} \mathrm{C} \mathrm{ha}^{-1} \mathrm{yr}^{-1}\right)$ by NT compared to CT as those 
https://doi.org/10.5194/bg-2022-6

Preprint. Discussion started: 7 February 2022

(c) Author(s) 2022. CC BY 4.0 License.

\section{(c) (i)}

found in a 3-year study by Franzluebbers and Stuedemann (2008). The same study, however, reported no losses in SOC stocks over time by using NT after grassland conversion. These results were obtained at a site with similar soil texture as in the present study, but with much higher precipitation (1250 vs. $847 \mathrm{~mm} \mathrm{yr}^{-1}$ ) and much lower initial SOC stocks ( $\sim 35$ vs. $\left.~ 74 \mathrm{Mg} \mathrm{ha}^{-1}\right)$. In another study, no losses in SOC stocks were found 6 years after a grassland was converted to continuous maize using NT, at a site with high initial SOC stocks ( $\left.\sim 91 \mathrm{Mg} \mathrm{ha}^{-1}\right)$ but with different soil texture (silt loam vs. sandy loam) combined with an extended drought period (Follett et al., 2009). However, a previously applied soil carbon model calibrated with soil carbon and yield data from the presented experimental site confirm the decay of SOC regardless of soil tillage method used (Reinsch et al., 2021).

Possible explanations for these differences might be associated with factors related to site conditions. Site conditions can play an important role in regulating both the rate of SOC formation and decomposition. For instance, high precipitation and a positive soil water balance can stimulate both high SOC formation and decomposition rates (Guo and Gifford, 2002). These rates can be proportional to the initial C content, the soil C balance, and the amount of silt and clay protecting the SOC (Paul et al., 1996). At our study site, a moist temperate climate is combined with comparably high SOC stocks in sandy loam soil. Under these conditions, high decomposition rates likely caused the loss of SOC after grassland conversion also in the NT-CM treatment.

Contrary to the results observed for grassland conversion, using NT during grassland renovation (NT-GR) conserved SOC stocks and showed no differences in the 0-30 cm layer compared to the GC (Figs 1 and 2). Results for NT use for the conservation of SOC stocks during grassland renovation are scarce. Existing studies report non-conclusive results regarding the advantages of NT over CT during grassland renovation. For instance, Linsler et al. (2013) reported no differences in SOC stocks between a grassland that was renovated using CT and the adjacent undisturbed grassland system, sampled five years after renovation. Similarly, Gaweł and Grzelak (2020) observed no changes in SOC stocks over time in neither NT nor CT during grassland renovation in the 0-30 cm layer sampled 3 years after renovation. In contrast, a $25 \%$ reduction in SOC stocks was observed 2.5 years after a single use of CT for grassland renovation, compared to the adjacent undisturbed grassland in a study located in a temperate wet region (Necpálová et al., 2014). Since our study did not include a grassland renovation treatment using CT, conclusions about how much SOC losses were avoided by replacing CT with NT for renovation cannot be drawn directly. However, by comparing GR with GC it can be deduced that the SOC balance was not affected by the grassland renovation measure using NT. However, in intensive grassland systems renovation occurs usually in intervals after 5 and 10 years, respectively. Reinsch et al., 2018 found that regular renovation can reduced the $\mathrm{C}$ sequestration rate of grasslands substantially compared to permanent grassland, thereof, improved grassland management instead of frequent grassland renovation should be sought.

Additionally, our observations are based on sequential annual soil sampling to determine annual SOC change rates, compared 250 to single soil samplings several years after ploughing and renovation events in other studies. This difference in methodology supports our results, by eliminating potential unseen effects caused by the sampling interval. 
https://doi.org/10.5194/bg-2022-6

Preprint. Discussion started: 7 February 2022

(c) Author(s) 2022. CC BY 4.0 License.

(c) (i)

\subsection{LUC and tillage effects on SOC in the subsoil}

Due to a lack of data, it is often recommended to observe the SOC dynamics in deeper soil layers to study the effects of LUC and tillage methods on the whole soil profile. It was hypothesized that the conversion or renovation of a permanent grassland negatively affects subsoil SOC. In this study, the cropping system effect on SOC was different for the different soil layers, while this was not the case for the effect of the tillage method in the subsoil (Table 2 and Table 3). Subsoil SOC stocks were significantly increasing in the $30-60 \mathrm{~cm}$ layer of the GC, whereas in the other systems it remained unchanged or was only slightly and insignificantly affected (Table 2 and Table 3, Figure 1 and Figure 2).

Reasons for the observed differences between the GC and the other systems might be attributed to changes in vegetation and its effects on the amount and distribution of $\mathrm{BG} \mathrm{C}_{\mathrm{i}}$, mainly roots and water-soluble $\mathrm{C}$ compounds, as indicated in other studies (Guo and Gifford, 2002; Post and Kwon, 2000). Due to its high solubility in water, DOC can be the most important C source and flux in subsoils (Kaiser and Kalbitz, 2012; Don and Schulze, 2008). It has been found highly associated not only with the production of $\mathrm{AG}$ and $\mathrm{BG}$ crop residues, rhizodeposits, and with the easily degradable $\mathrm{C}$ fraction, but also to be highly sensitive to soil disturbance and soil properties (Haynes, 2000; Guo and Gifford, 2002). Higher amounts of DOC have been observed in soils under both permanent grasslands and the grassland phase of a ley-arable rotation compared to arable soils (Gentile et al., 2005; Haynes, 2000). It has been found that chemical fallowing with or without ploughing reduced DOC levels in the subsoil compared to an undisturbed grassland (MacDonald et al., 2011). Don and Schulze (2008) observed a reduction in the export of DOC after ploughing a grassland, and that this export was higher in a sandy than in a clayey soil, indicating the adsorption of DOC by the clay fraction.

As frequently observed, the combination of low temperatures and waterlogging, as typical conditions in many subsoils, impedes the decomposition of SOC fractions (Necpálová et al., 2014; Freibauer et al., 2004). Although it was not measured, it is likely that high amounts of DOC are being produced and leached from the rooting zone of the GC, facilitated by the sandy texture of the topsoil and accumulated in the clay-enriched and frequently waterlogged subsoil, typical for stagnic Luvisols, where SOC is slowly decomposed (Jobbagy and Jackson, 2000).

A reduction in soil C sequestration was also observed in NT-GR, where it is likely that the existing root formation and decay dynamics were affected temporarily or permanently by eliminating the old grassland containing a well-developed root system formed by several grass and legume species, an effect that was also described by Kayser et al. (2018). Increasing SOC stocks in the subsoil, as observed under GC, could be expected in NT-GR if the initial conditions promoting SOC in the subsoil are restored after some time, as implied in other studies (Ogle et al., 2019a). These results suggest that SOC stocks in the subsoil can be affected by changes in vegetation and management as previously mentioned (VandenBygaart et al., 2011; Murugan et al., 2014; Nüsse et al., 2018).

When the whole soil profile was considered, the overall impact of grassland conversion and renovation on SOC was negative compared to the GC. This occurred as a result of the ceased $\mathrm{C}$ sequestration in the subsoil after both renovation and conversion, as well as from the strong decline in topsoil SOC after conversion (Table 4, Figs 3 and 4).In other studies, opposite results 
https://doi.org/10.5194/bg-2022-6

Preprint. Discussion started: 7 February 2022

(c) Author(s) 2022. CC BY 4.0 License.

(c) (i)

285 have been observed down to $1 \mathrm{~m}$ depth, when arable land and forests soils have been converted to grasslands. Grassland soils have been shown to increase the amount and proportion of SOC in deeper layers,compared to other land use types like arable lands (Post and Kwon, 2000; Guo and Gifford, 2002; Jobbagy and Jackson, 2000). These findings address the sensitivity of subsoil SOC to LUC, and thus emphasize the need of sampling deeper than the common $30 \mathrm{~cm}$ layer, as suggested in several studies (VandenBygaart et al., 2011; Christopher et al., 2009; Gál et al., 2007; Wanniarachchi et al., 1999).

\subsection{Soil C input effects on annual SOC changes $(\triangle S O C)$}

It was hypothesized that soil $\mathrm{C}$ inputs from plant residues are the main controlling factor for SOC change rates in no-till systems. Confirming this hypothesis, we found a strong significant relationship between $\triangle \mathrm{SOC}$ and $\mathrm{C}_{\mathrm{i}}$ when data was pooled over the treatments NT-GR, NT-CM, and GC (Figure 5). This confirms the expected importance of $\mathrm{C}_{\mathrm{i}}$ to maintain SOC stocks at initial levels when management or land-use changes occur. According to earlier studies (Wilhelm et al., 2004; Follett, 2001;

295 Lal and Kimble, 1997), the equilibrium level of SOC can be linearly related to the amount of crop residues, given that all management practices with potential effects on SOC (e.g., soil erosion and SOC degradation rates by tillage) remain constant. Thus, conserving SOC stocks mainly relies on adequate levels of $\mathrm{C}_{\mathrm{i}}$ to balance system-specific SOC decomposition rates. Consequently, reduced amounts of mean annual crop residues returned to the soil would lead to losses of SOC from cropping systems (Poyda et al., 2019). In NT-CM, the mean annual soil $\mathrm{C}_{\mathrm{i}}$ was reduced by $74 \%$, whereas in NT-GR this reduction was only $6 \%$ compared to GC (Table 5). Approximately, $6.5 \mathrm{Mg} \mathrm{ha}^{-1} \mathrm{yr}^{-1}$ of soil $\mathrm{C}_{\mathrm{i}}$ from plant residues was required to maintain the SOC stocks at the initial level of the permanent grassland before the experiment ( $75 \mathrm{Mg} \mathrm{SOC} \mathrm{ha}^{-1}$; i.e., $\left.\Delta \mathrm{SOC}=0\right)$ (Johnson et al., 2006 and Johnson et al., 2014).

Our results indicate that NT is a suitable option to maintain SOC stocks when a grassland renovation measure seems unavoidable. The most likely explanation is that a lower soil $C_{i}$ due to reduced productivity in the renovation year is compensated by reduced microbial decomposition rates as a result of lower amounts of labile $\mathrm{C}$ entering the soil, which remains undisturbed. In the case of grassland conversion, however, these effects were not sufficient to compensate for the strongly reduced soil $\mathrm{C}_{\mathrm{i}}$ under NT-CM. These results indicate that site conditions are of overriding importance for the efficiency of NT for SOC conservation after grassland conversion, as postulated by Guo and Gifford (2002) and Conant et al. (2001).

\section{Conclusions}

310 In this study, the impacts of LUC from grassland to arable land as well as that of tillage methods on SOC stocks after grassland conversion and renovation were evaluated for the whole soil profile. Opposite to what some studies suggested, NT could not conserve SOC stocks after LUC, but it strongly reduced their losses compared to CT and demonstrated that SOC stocks can be conserved when NT was used for grassland renovation under the conditions of the study site. The much lower soil $\mathrm{C}_{\mathrm{i}}$ compared to the grassland systems was the most important reason for the observed SOC losses under NT-CM. Interestingly,

315 the permanent grassland was still accumulating SOC, which could not have been observed if only the topsoil was sampled, 
https://doi.org/10.5194/bg-2022-6

Preprint. Discussion started: 7 February 2022

(c) Author(s) 2022. CC BY 4.0 License.

(c) (i)

and this process was interrupted even by a grassland renovation using NT. This strengthens the need to consider the SOC changes occurring in the whole profile, as ongoing $\mathrm{C}$ sequestration might be occurring in deeper soil layers, even when soil $\mathrm{C}$ saturation has been already achieved in the topsoil.

\section{Appendix A}

The supplement related to this article is available online doi: https://doi.org//xxxxxx

Author Contributions: Conceptualization, J.DLR., A.P., T.R., R.L., and F.T.; Methodology, J.DLR., A.P., and T.R.; Software, J.DLR.; Formal analysis, J.DLR.; Investigation, J.DLR.; Data curation, C. K., J.DLR.; Writing—original draft preparation, 325 J.DLR.; Writing — review and editing, A.P., T.R., and F.T; Visualization, J.DLR.; Supervision, A.P., T.R., and F.T.; Funding acquisition, T.R. and F.T.

Competing interests. The authors declare that they have no conflict of interest.

330 Financial support: J.DLR. is supported by the Evangelisches Studienwerk Villigst foundation, under the research program: "Third Ways of Feeding the World" in the form of a doctoral scholarship. This research was financially supported by the Stiftung Schleswig-Holsteinische Landschaft. The Land Schleswig-Holstein provided financial support within the funding program Open Access Publikationsfonds. Their financial support is gratefully acknowledged.

335 Acknowledgments. The authors thank Prof. Dr. Mario Hasler for the valuable statistical consultancy, HORSCH Maschinen GmbH for the technical assistance, and R. Kopp, K. Helmich, M. Hansen, T. Ehmsen and R. Ströh for their expert technical support during the fieldwork and lab analyses.

\section{References}

Angers, D. A. and Eriksen-Hamel, N. S.: Full-Inversion tillage and organic carbon distribution in soil profiles: A meta-analysis, 340 Soil Sci. Soc. Am. J., 72, 1370-1374, doi:10.2136/sssaj2007.0342, 2008.

Bates, D.; Mächler, M.; Bolker, B.; Walker, S. Fitting linear mixed-effects models using lme4. J. Stat. Soft., 67, doi:10.18637/jss.v067.i01, 2015.

Bolinder, M. A., Janzen, H. H., Gregorich, E. G., Angers, D. A., and VandenBygaart, A. J.: An approach for estimating net primary productivity and annual carbon inputs to soil for common agricultural crops in Canada, Agric. Ecosyst. Environ., 118, 345 29-42, doi:10.1016/j.agee.2006.05.013, 2007. 
https://doi.org/10.5194/bg-2022-6

Preprint. Discussion started: 7 February 2022

(c) Author(s) 2022. CC BY 4.0 License.

\section{(c) (1)}

Christopher, S. F., Lal, R., and Mishra, U.: Regional study of no-till effects on carbon sequestration in the Midwestern United States, Soil Sci. Soc. Am. J., 73, 207-216, doi:10.2136/sssaj2007.0336, 2009.

Conant, R. T., Paustian, K., and Elliott, E. T.: Grassland management and conversion into grassland: Effects on soil carbon, Ecol. Appl., 11, 343-355, doi:10.1890/1051-0761(2001)011[0343:GMACIG]2.0.CO;2, 2001.

Diabate, B., Wang, X., Gao, Y., Yu, P., Wu, Z., Zhou, D., and Yang, H.: Tillage and haymaking practices speed up belowground net productivity restoration in the degraded Songnen grassland, Soil Tillage Res., 175, 62-70, doi:10.1016/j.still.2017.08.003, 2018.

Don, A. and Schulze, E.-D.: Controls on fluxes and export of dissolved organic carbon in grasslands with contrasting soil types, Biogeochemistry, 91, 117-131, doi:10.1007/s10533-008-9263-y, 2008.

Ellert, B. H., Janzen, H. H., VandenBygaart, A. J., and Bremer, E.: Measuring change in soil organic carbon storage, in: Soil sampling and methods of analysis, 2nd, Gregorich, E. G., Carter, M. R. (Eds.), CRC Press, 2008.

Ferreira, A. d. O., Sá, J. C. d. M., Harms, M. G., Miara, S., Briedis, C., Quadros Netto, C., Santos, J. B. d., and Canalli, L. B.: Carbon balance and crop residue management in dynamic equilibrium under a no-till system in Campos Gerais, Rev. Bras. Ciênc. Solo, 36, 1583-1590, doi:10.1590/S0100-06832012000500022, 2012.

360 Follett, R. F.: Soil management concepts and carbon sequestration in cropland soils, Soil Tillage Res., 61, 77-92, doi:10.1016/S0167-1987(01)00180-5, 2001.

Follett, R. F., Varvel, G. E., Kimble, J. M., and Vogel, K. P.: No-till corn after bromegrass: Effect on soil carbon and soil aggregates, Agron. J., 101, 261-268, doi:10.2134/agronj2008.0107, 2009.

Franzluebbers, A. J. and Stuedemann, J. A.: Early response of soil organic fractions to tillage and integrated crop-livestock production, Soil Sci. Soc. Am. J., 72, 613-625, doi:10.2136/sssaj2007.0121, 2008.

Freibauer, A., Rounsevell, M. D., Smith, P., and Verhagen, J.: Carbon sequestration in the agricultural soils of Europe, Geoderma, 122, 1-23, doi:10.1016/j.geoderma.2004.01.021, 2004.

Gál, A., Vyn, T. J., Michéli, E., Kladivko, E. J., and McFee, W. W.: Soil carbon and nitrogen accumulation with long-term no-till versus moldboard plowing overestimated with tilled-zone sampling depths, Soil Tillage Res., 96, 42-51, doi:10.1016/j.still.2007.02.007, 2007.

Gaweł, E. and Grzelak, M.: The influences of different methods of grassland renovation on the weight of post-harvest residues and the abundance of selected soil nutrients, Agronomy, 10, 1590, doi:10.3390/agronomy10101590, 2020.

Gentile, R. M., Martino, D. L., and Entz, M. H.: Influence of perennial forages on subsoil organic carbon in a long-term rotation study in Uruguay, Agric. Ecosyst. Environ., 105, 419-423, doi:10.1016/j.agee.2004.05.002, 2005.

375 Guo, L. B. and Gifford, R. M.: Soil carbon stocks and land use change: a meta analysis, Global Change Biol, 8, 345-360, doi:10.1046/j.1354-1013.2002.00486.x, 2002.

Haynes, R. J.: Labile organic matter as an indicator of organic matter quality in arable and pastoral soils in New Zealand, Soil Biol. Biochem., 32, 211-2019, doi:10.1016/S0038-0717(99)00148-0, 2000. 
https://doi.org/10.5194/bg-2022-6

Preprint. Discussion started: 7 February 2022

(c) Author(s) 2022. CC BY 4.0 License.

(c) (i)

ISO: Soil quality — Determination of organic and total carbon after dry combustion (elementary analysis), 13.080.10:

https://www.iso.org/standard/18782.html.

Jobbagy, E. G. and Jackson, R. B.: The Vertical Distribution of Soil Organic Carbon and Its Relation to Climate and Vegetation, Ecol. Appl., 10, 423, doi:10.2307/2641104, 2000.

Johnson, J. M. F., Novak, J. M., Varvel, G. E., Stott, D. E., Osborne, S. L., Karlen, D. L., Lamb, J. A., Baker, J., and Adler, P.

R.: Crop residue mass needed to maintain soil organic carbon levels: Can it be determined?, Bioenerg. Res., 7, 481-490,

doi:10.1007/s12155-013-9402-8, 2014.

Johnson, J. M.-F., Allmaras, R. R., and Reicosky, D. C.: Estimating source carbon from crop residues, roots and rhizodeposits using the National Grain-Yield Database, Agron. J., 98, 622, doi:10.2134/agronj2005.0179, 2006.

Kaiser, K. and Kalbitz, K.: Cycling downwards - dissolved organic matter in soils, Soil Biol. Biochem., 52, 29-32, doi:10.1016/j.soilbio.2012.04.002, 2012.

390 Kayser, M., Müller, J., and Isselstein, J.: Grassland renovation has important consequences for C and N cycling and losses, Food Energy Secur, 7, e00146, doi:10.1002/fes3.146, 2018.

Kern, J. S. and Johnson, M. G.: Conservation tillage impacts on national soil and atmospheric carbon levels, Soil Sci. Soc. Am. J, 57, 200-2010, doi:10.2136/SSSAJ1993.03615995005700010036X, 1993.

Lal, R. and Follett, R. F.: Soil Carbon Sequestration and the Greenhouse Effect, 2nd ed., SSSA special publication, 57, Soil

395 Sci. Soc. Am. J., Madison WI, xxviii, 410 [8] of col. plates, 2009.

Lal, R. and Kimble, J. M.: Conservation tillage for carbon sequestration, Nutr. Cycl. Agroecosyst., 49, 243-253, doi:10.1023/A:1009794514742, 1997.

Linsler, D., Geisseler, D., Loges, R., Taube, F., and Ludwig, B.: Temporal dynamics of soil organic matter composition and aggregate distribution in permanent grassland after a single tillage event in a temperate climate, Soil Tillage Res., 126, 90-99, 400 doi:10.1016/j.still.2012.07.017, 2013.

Luo, Z., Wang, E., and Sun, O. J.: Can no-tillage stimulate carbon sequestration in agricultural soils?: A meta-analysis of paired experiments, Agric. Ecosyst. Environ., 139, 224-231, doi:10.1016/j.agee.2010.08.006, 2010.

MacDonald, J. D., Chantigny, M. H., Angers, D. A., Rochette, P., Royer, I., and Gasser, M.-O.: Soil soluble carbon dynamics of manured and unmanured grasslands following chemical kill and ploughing, Geoderma, 164, 64-72, 405 doi:10.1016/j.geoderma.2011.05.011, 2011.

Murugan, R., Loges, R., Taube, F., Sradnick, A., and Joergensen, R. G.: Changes in soil microbial biomass and residual indices as ecological indicators of land use change in temperate permanent grassland, Microb. Ecol., 67, 907-918, doi:10.1007/s00248-014-0383-8, 2014.

Necpálová, M., Li, D., Lanigan, G., Casey, I. A., Burchill, W., and Humphreys, J.: Changes in soil organic carbon in a clay

410 loam soil following ploughing and reseeding of permanent grassland under temperate moist climatic conditions, Grass Forage Sci, 69, 611-624, doi:10.1111/gfs.12080, 2014. 
https://doi.org/10.5194/bg-2022-6

Preprint. Discussion started: 7 February 2022

(c) Author(s) 2022. CC BY 4.0 License.

\section{(c) (1)}

Nüsse, A., Linsler, D., Loges, R., Reinsch, T., Taube, F., and Ludwig, B.: Effect of grassland harvesting frequency and Nfertilization on stocks and dynamics of soil organic matter in the temperate climate, Arch. Acker Pflanzenbau Bodenkd., 64, 1925-1931, doi:10.1080/03650340.2018.1468561, 2018.

415 Ogle, S. M., Alsaker, C., Baldock, J., Bernoux, M., Breidt, F. J., McConkey, B., Regina, K., and Vazquez-Amabile, G. G.: Climate and soil characteristics determine where no-till management can store carbon in soils and mitigate greenhouse gas emissions, Sci. Rep., 9, 11665, doi:10.1038/s41598-019-47861-7, 2019a.

Ogle, S. M., Wakelin, S. J., Buendia, L., McConkey, B., Baldock, J., Akiyama, H., Mo Kishimoto, A. W., Chirinda, N., Bernoux, M., Bhattacharya, S. N., Chuersuwan, N., Rashid Goheer, M. A., Hergoualc’h, K., Ishizuka, S., Diaz Lasco, R., Pan,

420 X., Pathak, H., Regina, K., Sato, A., Vazquez-Amabile, G., Wang, C., and Zheng, X.: Chapter 5 Cropland, in: 2019 Refinement to the 2006 IPCC Guidelines for National Greenhouse Gas Inventories, Calvo Buendia, E., Tanabe, K., Kranjc, A., Baasansuren, J., Fukuda, M., Ngarize S., O., A., Pyrozhenko, Y., Shermanau, P., Federici, S. (Eds.), Agriculture, Forestry and Other Land use, 4, IPCC, Switzerland, 2019b.

Paul, E. A., Elliott, E. T., Paustian, K., and Cote, C. V. (Eds.): Soil Organic Matter in Temperate Agroecosystems: Long-Term Experiments in North America, 1st, CRC Press, 433 pp., 1996.

Pausch, J. and Kuzyakov, Y.: Carbon input by roots into the soil: Quantification of rhizodeposition from root to ecosystem scale, Glob. Chang. Biol., 24, 1-12, doi:10.1111/gcb.13850, 2018.

Post, W. M. and Kwon, K. C.: Soil carbon sequestration and land-use change: processes and potential, Glob. Chang. Biol., 6, 317-327, doi:10.1046/j.1365-2486.2000.00308.x, 2000.

430 Poyda, A., Wizemann, H.-D., Ingwersen, J., Eshonkulov, R., Högy, P., Demyan, M. S., Kremer, P., Wulfmeyer, V., and Streck, T.: Carbon fluxes and budgets of intensive crop rotations in two regional climates of southwest Germany, Agric. Ecosyst. Environ., 276, 31-46, doi:10.1016/j.agee.2019.02.011, 2019.

R Core Team: R: A Language and Environment for Statistical Computing, R Foundation for Statistical Computing, Vienna, Austria, 2020.

435 Reinsch, T., Loges, R., Kluß, C., and Taube, F.: Effect of grassland ploughing and reseeding on CO2 emissions and soil carbon stocks, Agric. Ecosyst. Environ., 265, 374-383, doi:10.1016/j.agee.2018.06.020, 2018a.

Reinsch, T., Loges, R., Kluß, C., and Taube, F.: Renovation and conversion of permanent grass-clover swards to pasture or crops: Effects on annual N 2 O emissions in the year after ploughing, Soil Tillage Res., 175, 119-129, doi:10.1016/j.still.2017.08.009, 2018b.

440 Reinsch, T., Struck, I. J. A., Loges, R., Kluß, C., and Taube, F.: Soil carbon dynamics of no-till silage maize in ley systems, Soil Tillage Res., 209, 104957, doi:10.1016/j.still.2021.104957, 2021.

Schmeer, M., Loges, R., Dittert, K., Senbayram, M., Horn, R., and Taube, F.: Legume-based forage production systems reduce nitrous oxide emissions, Soil Tillage Res., 143, 17-25, doi:10.1016/j.still.2014.05.001, 2014.

Smucker, A. J. M., McBurney, S. L., and Srivastava, A. K.: Quantitative separation of roots from compacted soil profiles by the hydropneumatic elutriation system, Agron. J., 74, 500-503, doi:10.2134/agronj1982.00021962007400030023x, 1982. 
https://doi.org/10.5194/bg-2022-6

Preprint. Discussion started: 7 February 2022

(c) Author(s) 2022. CC BY 4.0 License.

(c) (i)

Steingrobe, B., Schmid, H., and Claassen, N.: The use of the ingrowth core method for measuring root production of arable crops - influence of soil and root disturbance during installation of the bags on root ingrowth into the cores, Eur. J. Agron., 15, 143-151, doi:10.1016/S1161-0301(01)00100-9, 2001.

Struck, I.: No-tillage silage maize (Zea mays L.) in ley-arable systems - Crop performance and environmental effects under maritime climates, Doctoral thesis, Grassland and Forage Sciences/Organic Agriculture, Christian-Albrechts-University of Kiel, Kiel, 215 pp., 2018.

Struck, I. J., Reinsch, T., Herrmann, A., Kluß, C., Loges, R., and Taube, F.: Yield potential and nitrogen dynamics of no-till silage maize (Zea mays L.) under maritime climate conditions, Eur. J. Agron., 107, 30-42, doi:10.1016/j.eja.2019.04.009, 2019.

455 Thorn, E. R., Fraser, T. J., and Hume, D. E.: Sowing methods for successful pasture establishment - a review, in: Pasture Persistence Symposium, NZGA: Research and Practice Series, 31-38, 2011.

VandenBygaart, A. J., Bremer, E., McConkey, B. G., Ellert, B. H., Janzen, H. H., Angers, D. A., Carter, M. R., Drury, C. F., Lafond, G. P., and McKenzie, R. H.: Impact of Sampling Depth on Differences in Soil Carbon Stocks in Long-Term Agroecosystem Experiments, Soil Sci. Soc. Am. J., 75, 226-234, doi:10.2136/sssaj2010.0099, 2011.

460 Velthof, G. L., Hoving, I. E., Dolfing, J., Smit, A., Kuikman, P. J., and Oenema, O.: Method and timing of grassland renovation affects herbage yield, nitrate leaching, and nitrous oxide emission in intensively managed grasslands, Nutr. Cycl. Agroecosyst., 86, 401-412, doi:10.1007/s10705-009-9302-7, 2010.

Wanniarachchi, S. D., Voroney, R. P., Vyn, T. J., Beyaert, R. P., and MacKenzie, A. F.: Tillage effects on the dynamics of total and corn-residue-derived soil organic matter in two southern Ontario soils, Can. J. Soil. Sci., 473-484, doi:10.4141/S97465 096, 1999.

West, T. O. and Marland, G.: A synthesis of carbon sequestration, carbon emissions, and net carbon flux in agriculture: comparing tillage practices in the United States, Agric. Ecosyst. Environ., 91, 217-232, doi:10.1016/s0167-8809(01)00233-x, 2002.

West, T. O. and Post, W. M.: Soil organic carbon sequestration rates by tillage and crop Rotation: A global data analysis, Soil 470 Sci. Soc. Am. J., 66, 1930-1946, doi:10.2136/sssaj2002.1930, 2002.

Wilhelm, W. W., Johnson, J., Hatfield, J. L., Voorhees, W. B., Linden, and D.R.: Crop and soil productivity response to corn residue removal: A literature review, Agron. J., 96, 1-17, doi:10.2134/agronj2004.1000a, 2004. 
https://doi.org/10.5194/bg-2022-6

Preprint. Discussion started: 7 February 2022

(c) Author(s) 2022. CC BY 4.0 License.

480 Table 1. Soil textures and types of different layers at the study site (German system).

\begin{tabular}{lcccc}
\hline \multirow{2}{*}{ Layer $(\mathbf{c m})$} & \multicolumn{3}{c}{ Texture (\%) } & \multirow{2}{*}{ Soil type } \\
\cline { 2 - 4 } & Sand & Silt & Clay & \\
\hline $0-25$ & 54 & 30 & 16 & Highly loamy sand \\
$25-45$ & 50 & 31 & 19 & Medium sandy loam \\
$45-70$ & 49 & 33 & 18 & Medium sandy loam \\
$70-$ & 55 & 31 & 14 & Highly loamy sand \\
\hline
\end{tabular}

Table 2. Analysis of covariance (ANCOVA) to determine the influence of cropping system, N rate, soil layer, time, and their interactions on soil organic carbon (SOC) stocks after a 10-year utilization period as permanent grassland.

\begin{tabular}{lccc}
\hline Fixed-effects & Degrees of freedom $\dagger$ & F-value & P-value \\
\hline (Intercept) & $\mathbf{1 , 9 9 5}$ & $\mathbf{1 3 2 1 . 1 4}$ & $<.0001$ \\
Soil layer & $\mathbf{2 , 9 9 5}$ & $\mathbf{5 5 6 . 9 6}$ & $<.0001$ \\
N rate & 1,36 & 0.21 & 0.65 \\
Cropping System & 3,9 & 0.61 & 0.63 \\
Time & $\mathbf{1 , 4 2 4}$ & $\mathbf{5 3 . 8 1}$ & $<.0001$ \\
Soil layer $\times$ N rate & 2,955 & 0.54 & 0.58 \\
Soil layer $\times$ Cropping system & 6,955 & 1.95 & 0.07 \\
N rate $\times$ Cropping system & 3,36 & 0.18 & 0.91 \\
Soil layer $\times$ Time & $\mathbf{2 , 9 5 5}$ & $\mathbf{1 9 . 1 2}$ & $<.0001$ \\
N rate $\times$ Time & 1,424 & 0.51 & 0.48 \\
Cropping System $\times$ Time & $\mathbf{3 , 4 2 4}$ & $\mathbf{9 . 1 1}$ & $<.0001$ \\
Soil layer $\times$ N rate $\times$ Cropping system & 6,955 & 1.20 & 0.30 \\
Soil layer $\times$ N rate $\times$ Time & 2,955 & 0.28 & 0.76 \\
Soil layer $\times$ Cropping system $\times$ Time & $\mathbf{6 , 9 5 5}$ & $\mathbf{4 . 9 0}$ & $<.0001$ \\
N rate $\times$ Cropping system $\times$ Time & 3,424 & 0.20 & 0.90 \\
Soil layer $\times$ N rate $\times$ Cropping system $\times$ Time & 6,955 & 1.08 & 0.37 \\
\hline
\end{tabular}

$\dagger$ : Degrees of freedom (Numerator, Denominator)

Model $\mathrm{R}^{2}$ marginal $=0.88 ;$ conditional $=0.92$ 
https://doi.org/10.5194/bg-2022-6

Preprint. Discussion started: 7 February 2022

(c) Author(s) 2022. CC BY 4.0 License.

Table 3. Analysis of covariance (ANCOVA) to determine the influence of tillage method, $\mathrm{N}$ rate, soil layer, time, and their interactions on soil organic carbon (SOC) stocks in the continuous silage maize systems (CM) after conversion of a 10-year-old permanent grassland.

\begin{tabular}{lccc}
\hline Fixed-effects & Degrees of freedom $\dagger$ & F-value & P-value \\
\hline (Intercept) & $\mathbf{1 , 6 4 1}$ & $\mathbf{1 3 1 0 . 6 4}$ & $<.0001$ \\
Soil layer & $\mathbf{2 , 6 4 1}$ & $\mathbf{5 5 6 . 7 5}$ & $<.0001$ \\
N rate & 1,22 & 0.19 & 0.66 \\
Tillage & 1,3 & 1.28 & 0.34 \\
Time & $\mathbf{1 , 2 8 4}$ & $\mathbf{5 3 . 2 1}$ & $<.0001$ \\
Soil layer $\times$ N rate & 2,641 & 0.55 & 0.58 \\
Soil layer $\times$ Tillage & 2,641 & 1.67 & 0.19 \\
N rate $\times$ Tillage & 1,22 & 0.24 & 0.63 \\
Soil layer $\times$ Time & $\mathbf{2 , 6 4 1}$ & $\mathbf{1 8 . 9 9}$ & $<.0001$ \\
N rate $\times$ Time & 1,284 & 0.50 & 0.48 \\
Tillage $\times$ Year & $\mathbf{1 , 2 8 4}$ & $\mathbf{6 . 8 4}$ & $<\mathbf{0 . 0 1}$ \\
Soil layer $\times$ N rate $\times$ Tillage & 2,641 & 1.01 & 0.37 \\
Soil layer $\times$ N rate $\times$ Time & 2,641 & 0.28 & 0.75 \\
Soil layer $\times$ Tillage $\times$ Time & 2,641 & 1.86 & 0.16 \\
N rate $\times$ Tillage $\times$ Time & 1,284 & 0.10 & 0.75 \\
Soil layer $\times$ N rate $\times$ Tillage $\times$ Time & 2,641 & 1.30 & 0.27 \\
\hline
\end{tabular}

$\dagger$ : Degrees of freedom (Numerator, Denominator)

Model $\mathrm{R}^{2}$ marginal $=0.86 ;$ conditional $=0.91$ 
https://doi.org/10.5194/bg-2022-6

Preprint. Discussion started: 7 February 2022

(c) Author(s) 2022. CC BY 4.0 License.

(c) (1)

Table 4. Analysis of covariance (ANCOVA) to determine the influence of cropping system, $\mathrm{N}$ rate, time, and their interactions on soil organic carbon (SOC) stocks across the whole soil profile $(0-90 \mathrm{~cm})$ after a 10-year utilization period as permanent grassland.

\begin{tabular}{lccc}
\hline Fixed-effects & Degrees of freedom $\dagger$ & F-value & P-value \\
\hline (Intercept) & 1,424 & 691.39 & $<.0001$ \\
N rate & 1,36 & 1.71 & 0.20 \\
Cropping System & 3,9 & 0.77 & 0.54 \\
Time & $\mathbf{1 , 4 2 4}$ & $\mathbf{2 7 . 4 7}$ & $<.0001$ \\
N rate $\times$ Cropping system & 3,36 & 0.99 & 0.41 \\
N rate $\times$ Time & 1,424 & 0.58 & 0.45 \\
Cropping system $\times$ Time & $\mathbf{3 , 4 2 4}$ & $\mathbf{5 . 8 5}$ & $<.001$ \\
N rate $\times$ Cropping system $\times$ Time & 3,424 & 1.49 & 0.22 \\
\hline
\end{tabular}

$\dagger$ : Degrees of freedom (Numerator, Denominator)

Model $\mathrm{R}^{2}$ marginal $=0.13 ;$ conditional $=0.99$

505 Table 5. Mean and standard deviation (S.D.) of annual soil carbon inputs $\left(\mathrm{C}_{\mathrm{i}}\right)$ from above- (AG) and belowground (BG) plant residues calculated for the different cropping systems and $\mathrm{N}$ rates at the study site. Estimates are representative of 16 replicates for GC, 8 replicates for NT-GR, and 24 replicates each for NT-CM and CT-CM.

\begin{tabular}{llccc}
\hline \multirow{2}{*}{ Cropping System } & \multirow{2}{*}{ N rate } & AG C & BG C $_{\mathbf{i}}$ & Total C $_{\mathbf{i}}$ \\
\cline { 3 - 5 } & & \multicolumn{3}{c}{ Mean (SD) $\left(M g C h a^{-1} y r^{-1}\right)$} \\
\hline GC & N0 & $1.0(0.3)$ & $7.3(2.8)$ & $8.2(3.1)$ \\
GC & N1 & $1.4(0.3)$ & $3.8(0.9)$ & $5.3(1.1)$ \\
NT-GR & N0 & $0.9(0.3)$ & $6.1(2.7)$ & $7.0(3.0)$ \\
NT-GR & N1 & $1.3(0.3)$ & $3.7(0.9)$ & $5.0(1.2)$ \\
NT-CM & N0 & $0.6(0.2)$ & $1.2(0.3)$ & $1.8(0.5)$ \\
NT-CM & N1 & $0.8(0.2)$ & $1.0(0.3)$ & $1.9(0.5)$ \\
CT-CM & N0 & $0.7(0.2)$ & $0.9(0.2)$ & $1.6(0.5)$ \\
CT-CM & N1 & $0.9(0.1)$ & $0.9(0.1)$ & $1.8(0.3)$ \\
\hline
\end{tabular}

GC: grassland control (undisturbed permanent grassland); NT-GR: grassland renovation with no-tillage;

NT-CM: continuous silage maize with no-tillage; CT-CM: continuous silage maize with conventional tillage; N0: non-fertilized; N1: fertilized with CAN based on a crop demand of $380 \mathrm{~kg} \mathrm{~N} \mathrm{ha}^{-1} \mathrm{yr}^{-1}$ for the grassland systems of $180 \mathrm{~kg} \mathrm{~N} \mathrm{ha}^{-1} \mathrm{yr}^{-1}$ for the silage maize systems. 
https://doi.org/10.5194/bg-2022-6

Preprint. Discussion started: 7 February 2022

(c) Author(s) 2022. CC BY 4.0 License.
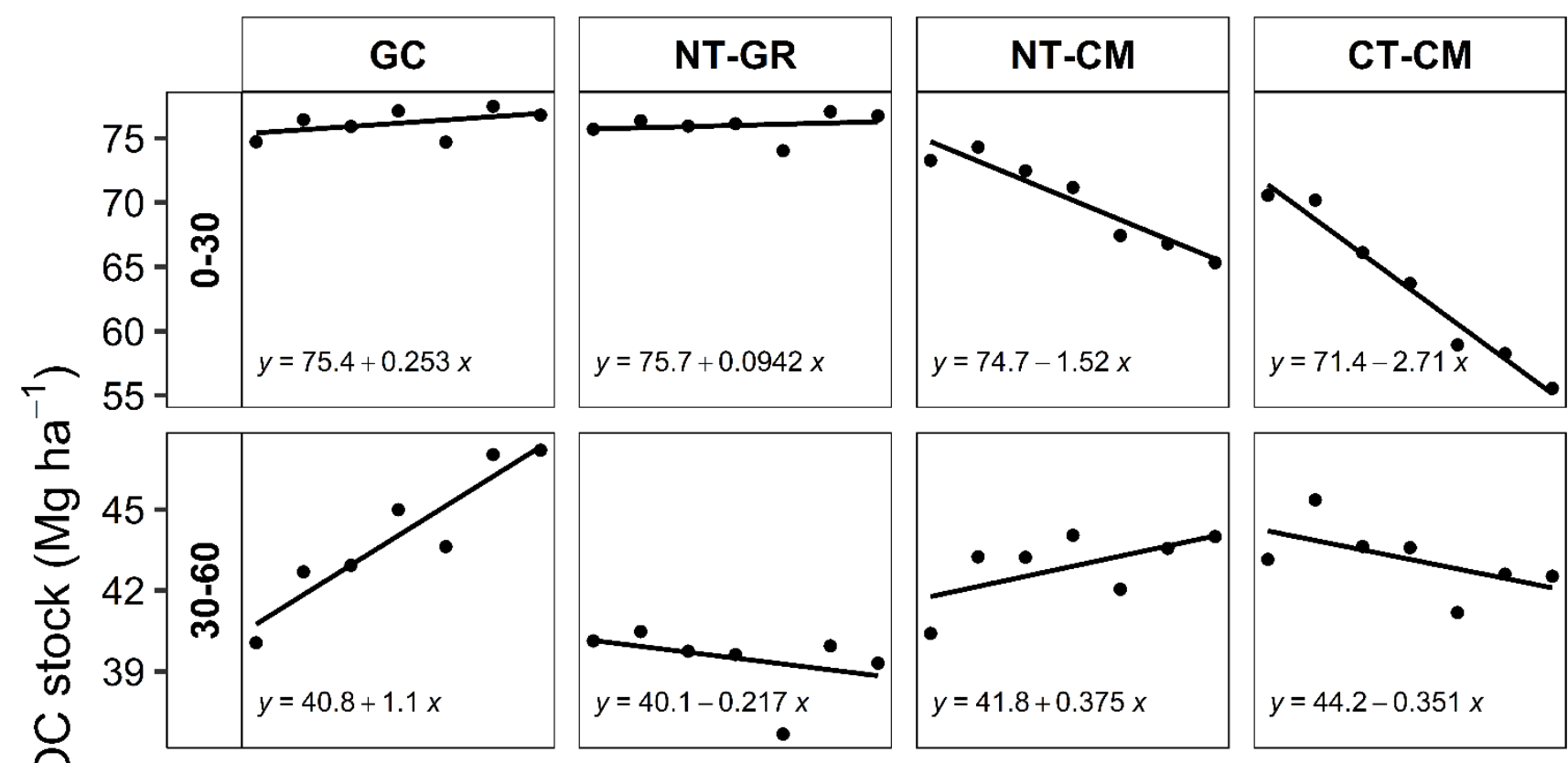

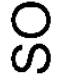
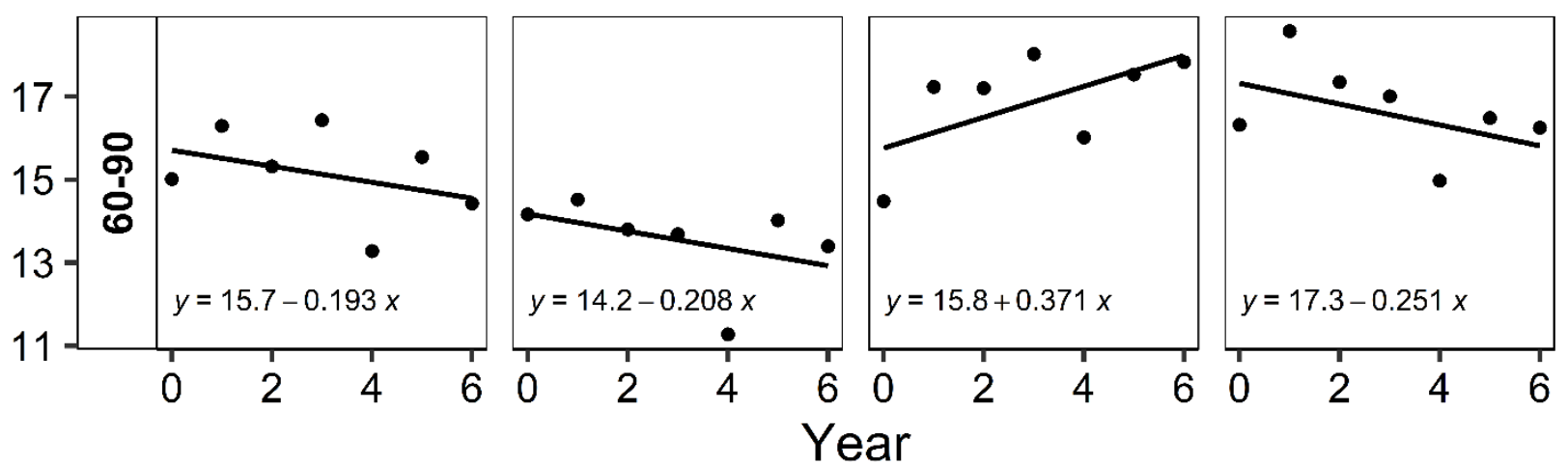

Figure 1. Mean temporal development of soil organic carbon (SOC) stocks in the different cropping systems and layers for the period 2014 - 2020, pooled over the two N rates. GC stands for undisturbed grassland control, NT-GR for no-till grassland renovation, NT-CM for notill continuous silage maize, and CT-CM for conventionally tilled continuous silage maize. Regression estimates are representative of 16 replicates for GC, 8 replicates for NT-GR, and 24 replicates each for NT-CM and CT-CM. 
https://doi.org/10.5194/bg-2022-6

Preprint. Discussion started: 7 February 2022

(c) Author(s) 2022. CC BY 4.0 License.

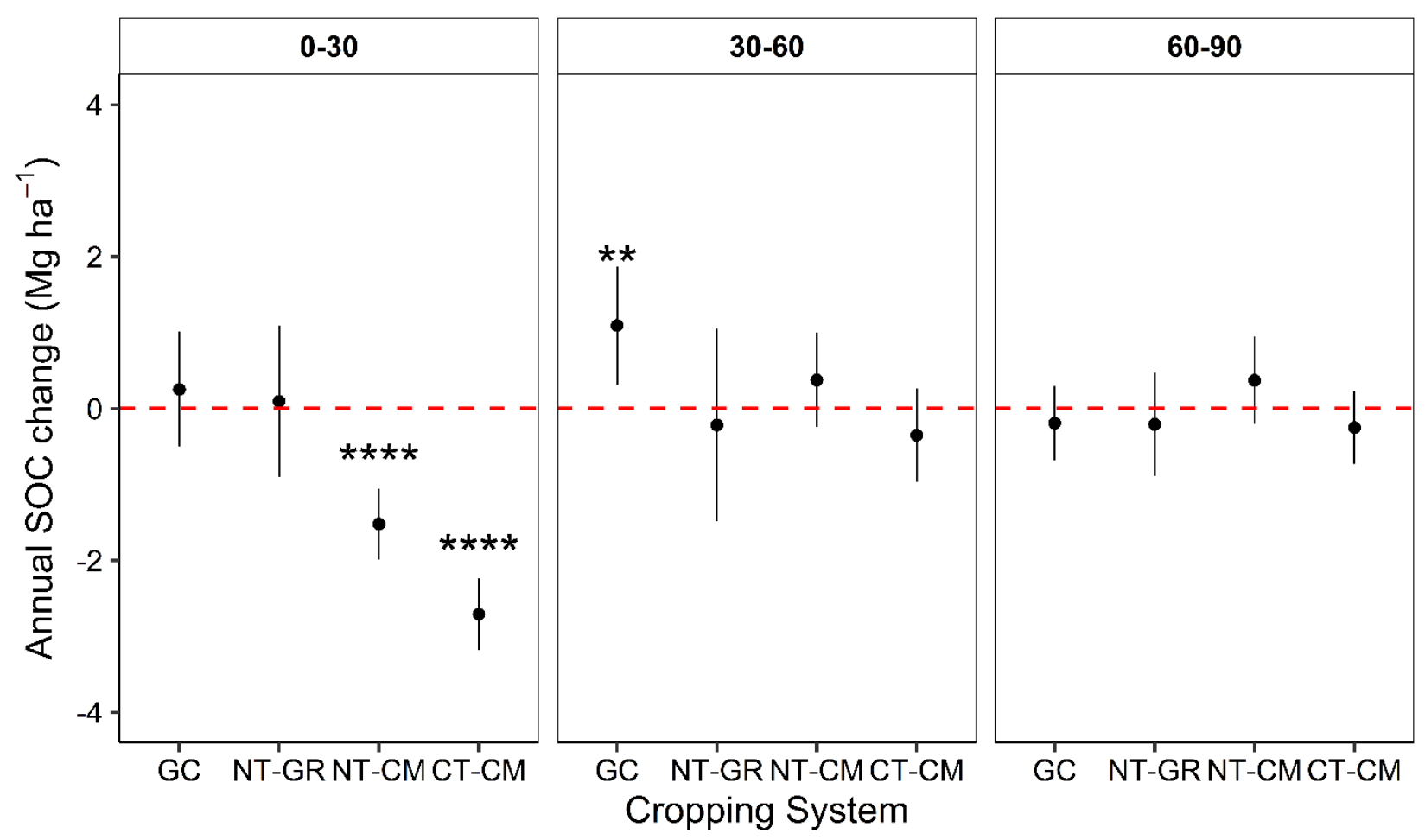

Figure 2. Mean annual SOC change rates ( $\pm 95 \%$ confidence intervals) for the different cropping systems during the period $2014-2020$, pooled over the two N rates. GC stands for grassland control, NT-GR for no-till grassland renovation, NT-CM for no-till continuous silage maize, and CT-CM for conventionally tilled continuous silage maize. Estimates are representative of 16 replicates for GC, 8 replicates for NT-GR, and 24 replicates each for NT-CM and CT-CM. Cropping systems with $*, * *, * * *$, or $* * * *$ indicate $\triangle$ SOC significantly differed from zero at $\mathrm{p}<0.05, \mathrm{p}<0.01, \mathrm{p}<0.001$ or at $\mathrm{p}<0.0001$, respectively. 
https://doi.org/10.5194/bg-2022-6

Preprint. Discussion started: 7 February 2022

(c) Author(s) 2022. CC BY 4.0 License.

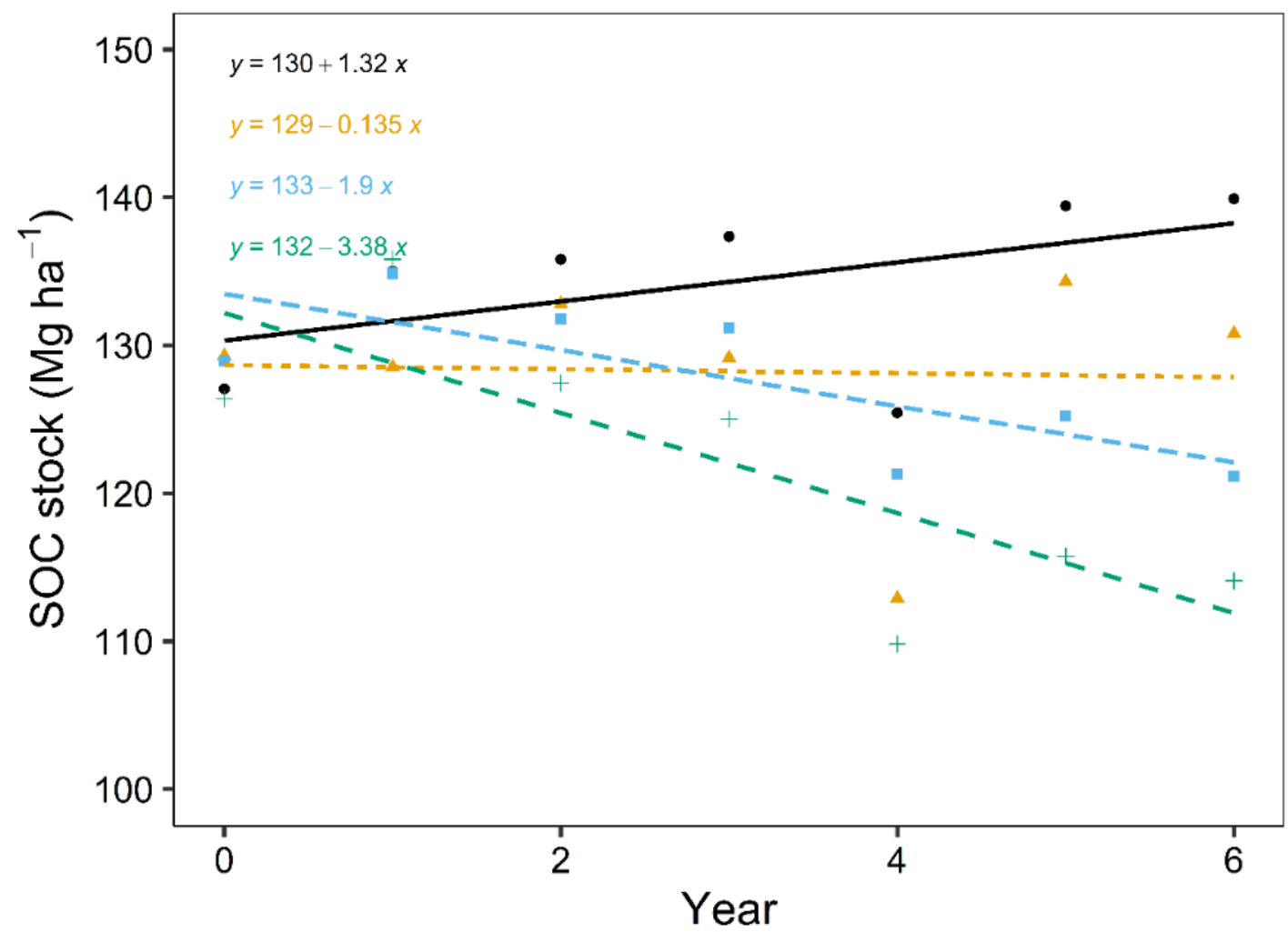

\section{Cropping System $\rightarrow$ GC $\sim$ NT-GR $\rightarrow$ NT-CM - CT-CM}

Figure 3. Mean temporal development of soil organic carbon (SOC) stocks for the different cropping systems across the 0-90 $\mathrm{cm}$ profile for the period 2014 - 2020, pooled over the two N rates. GC stands for grassland control, NT-GR for no-till grassland renovation, NT-CM for no-till continuous silage maize, and CT-CM for conventionally tilled continuous silage maize. Regression estimates are representative of 16 replicates for GC, 8 replicates for NT-GR, and 24 replicates each for NT-CM and CT-CM. 
https://doi.org/10.5194/bg-2022-6

Preprint. Discussion started: 7 February 2022

(c) Author(s) 2022. CC BY 4.0 License.
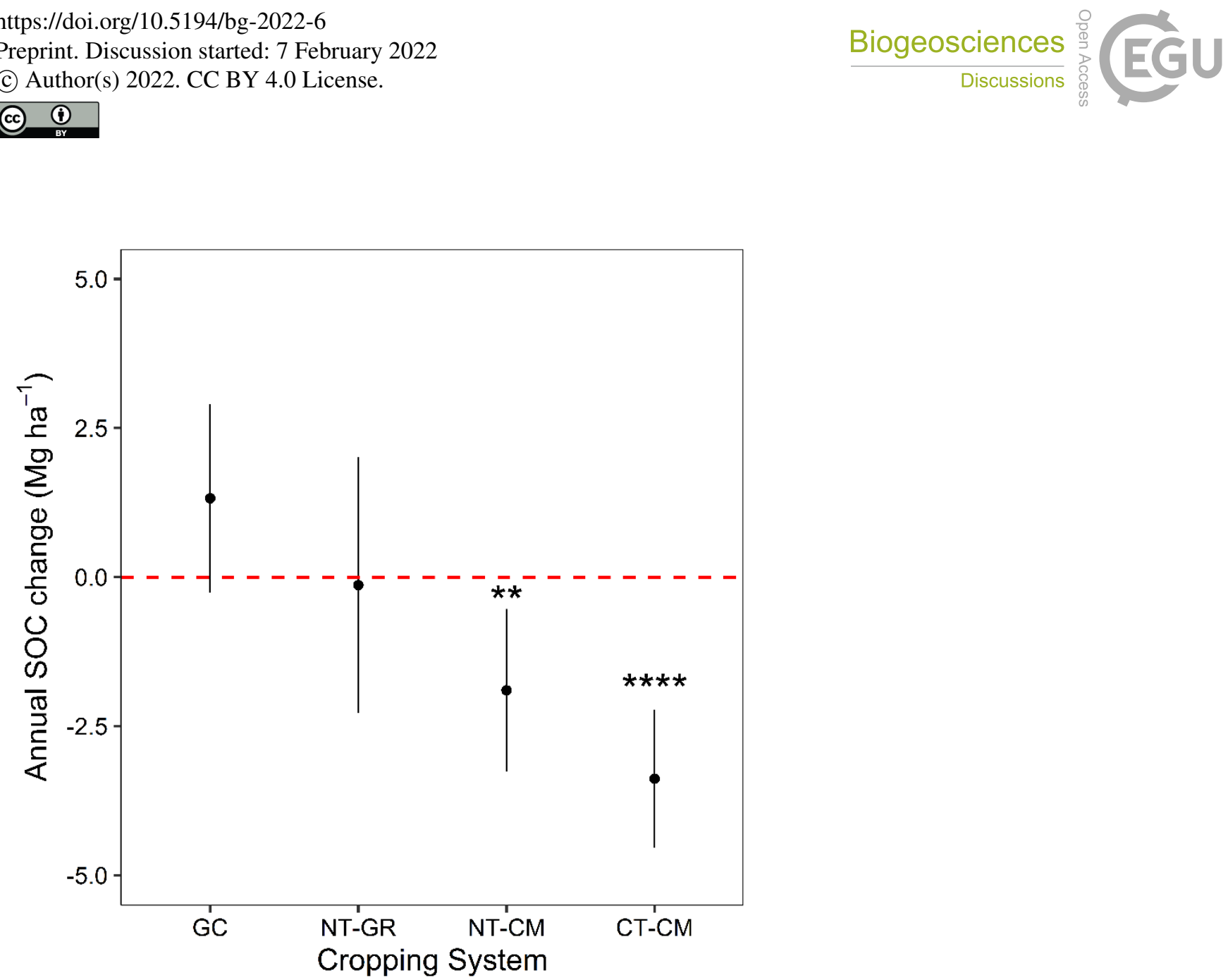

Figure 4. Mean annual SOC change rates ( $\pm 95 \%$ confidence intervals) in the $0-90 \mathrm{~cm}$ soil profile, pooled over the two $\mathrm{N}$ rates in the different cropping systems during the period 2014 - 2020. GC stands for grassland control, NT-GR for no-till grassland renovation, NT-CM for no-till continuous silage maize, and CT-CM for conventionally tilled continuous silage maize. Means are representative of 16 replicates for GC, 8 replicates for NT-GR, and 24 replicates each for NT-CM and CT-CM. Cropping systems with *,**, ***, or $* * * *$ indicate $\Delta$ SOC significantly differed from zero at $\mathrm{p}<0.05, \mathrm{p}<0.01, \mathrm{p}<0.001$ or at $\mathrm{p}<0.0001$, respectively. 
https://doi.org/10.5194/bg-2022-6

Preprint. Discussion started: 7 February 2022

(c) Author(s) 2022. CC BY 4.0 License.
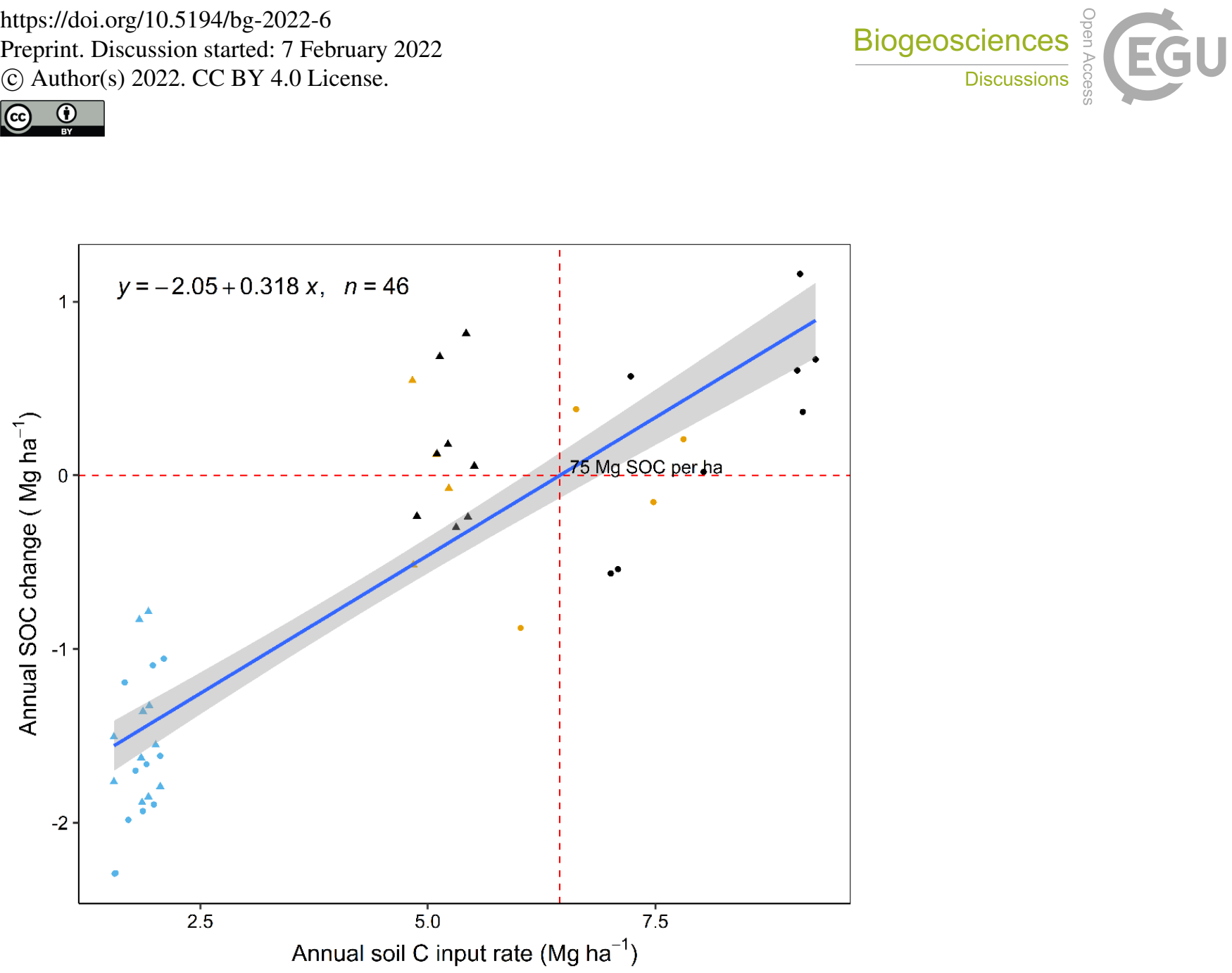

545

N rate - N0 \& N1 Cropping System • GC - NT-GR - NT-CM

Figure 5. Linear regression of annual soil organic carbon (SOC) change rates against annual soil C input rates from both above- and belowground biomass in the unploughed systems. Colors and shapes of the symbols indicate the replicates for the different cropping systems and N rates, respectively. GC stands for grassland control, NT-GR for no-till grassland renovation, and NT-CM for no-till continuous silage maize. The N0 and N1 refer to the non-fertilized and fertilized systems using CAN, respectively, based on a crop demand of $380 \mathrm{~kg}^{\mathrm{N}}$ ha ${ }^{-1}$ $\mathrm{yr}^{-1}$ for the grassland systems, and $180 \mathrm{~kg} \mathrm{~N} \mathrm{ha}^{-1} \mathrm{yr}^{-1}$ for the silage maize systems. 
https://doi.org/10.5194/bg-2022-6

Preprint. Discussion started: 7 February 2022

(c) Author(s) 2022. CC BY 4.0 License.

Table A1. Number of replicates observed in the different cropping systems and $\mathrm{N}$ rates, using the upper half of the experimental site since 2015, after their introduction into the 10-year-old permanent grassland (2004-2014). In the permanent grassland, the cutting frequencies comprised of 3 and 5 cuts $\mathrm{yr}^{-1}$, whereas the $\mathrm{N}$ application rates comprised of 0 and $360 \mathrm{~kg} \mathrm{~N} \mathrm{ha}^{-1} \mathrm{yr}^{-1}$. From 2015, the cropping systems comprised of an undisturbed permanent grassland as control (GC), a no-till grassland renovation (NT-GR), a no-till continuous silage maize (NT-CM) and a conventionally tilled continuous silage maize (CT-CM), whereas the N rates comprised of non-fertilized (N0) and fertilized systems (N1) with CAN, based on a crop demand of $380 \mathrm{~kg} \mathrm{~N} \mathrm{ha}^{-1} \mathrm{yr}^{-1}$ for the grassland systems and $180 \mathrm{~kg} \mathrm{~N}^{-1} \mathrm{yr}^{-1}$ for the silage maize systems.

\begin{tabular}{|c|c|c|c|c|c|c|}
\hline \multirow{3}{*}{$\begin{array}{c}\text { Cropping Systems } \\
\text { since } 2015\end{array}$} & \multirow{3}{*}{$\mathbf{N}$ rate } & \multicolumn{5}{|c|}{ Permanent Grassland (2004-2014) } \\
\hline & & \multicolumn{4}{|c|}{ Cutting frequency $x \mathrm{~N}$ rate levels } & \multirow{2}{*}{$\begin{array}{c}\text { Replicates by } \\
\text { treatment }\end{array}$} \\
\hline & & $3 \times 0$ & $5 \times 0$ & $3 \times 360$ & $5 \times 360$ & \\
\hline \multirow[t]{2}{*}{ GC } & N0 & 2 & 2 & 2 & 2 & 8 \\
\hline & N1 & 2 & 2 & 2 & 2 & 8 \\
\hline \multirow[t]{2}{*}{ NT-GR } & No & - & - & 2 & 2 & 4 \\
\hline & $\mathrm{N} 1$ & - & - & 2 & 2 & 4 \\
\hline \multirow[t]{2}{*}{ NT-CM } & N0 & 2 & 2 & 4 & 4 & 12 \\
\hline & N1 & 2 & 2 & 4 & 4 & 12 \\
\hline \multirow[t]{2}{*}{ CT-CM } & No & 2 & 2 & 4 & 4 & 12 \\
\hline & $\mathrm{N} 1$ & 2 & 2 & 4 & 4 & 12 \\
\hline \multicolumn{2}{|c|}{ Total number of replicates } & 12 & 12 & 24 & 24 & 72 \\
\hline
\end{tabular}

